\title{
An RT-PCR Assay for Detection of Infectious Bronchitis Coronavirus Serotypes
}

\author{
Junfeng Sun and Shengwang Liu
}

\begin{abstract}
Avian infectious bronchitis virus (IBV), a chicken Gammacoronavirus, is a major poultry pathogen, and is probably endemic in all regions with intensive poultry production. Since IBV was first described in 1936, many serotypes and variants of IBV have been isolated worldwide. IBV isolates are capable of infecting a large range of epithelial surfaces of the chicken, involving the respiratory, renal, and reproductive systems; however, the clinical signs are usually not specific for differential diagnoses. Virus isolation is commonly used for diagnosis of IBV infection, which was achieved through passage of clinical materials via the allantoic route of embryos. Currently, more sensitive molecular approaches for the detection of avian pathogens have been developed, including reverse-transcriptase polymerase chain reaction (RT-PCR) and real-time RT-PCR, which are more suitable for use in diagnostic laboratories. In this chapter, we describe a one-step RT-PCR which can be used for detecting most of IBV serotypes in the IBV-infected allantoic fluid and has been used routinely in our laboratories for detection of IBVs.
\end{abstract}

Key words IBV, RT-PCR, Molecular detection, Diagnosis, Clinical samples

\section{Introduction}

Infectious bronchitis (IB) is an acute and highly contagious viral disease of chicken caused by the infectious bronchitis virus (IBV). This disease is prevalent throughout the world and affects the performance of both meat-type and egg-laying birds, thereby causing severe economic loss within the poultry industry. IB can affect chickens of all ages and result in respiratory disease, nephritis, proventriculitis, and decrease in egg production and egg quality [1-3]. Furthermore, this disease is often complicated by secondary bacterial infections that cause increased mortality. It may be the most economically important viral respiratory tract disease of chickens in countries and regions where there is no highly pathogenic avian influenza virus or velogenic (highly pathogenic) Newcastle disease virus [4]. 
IBV is a gammacoronavirus of the subfamily Coronavirinae, family Coronaviridae, and order Nidovirales. The IBV genome is an approximately 27.6-kb linear, non-segmented, positive-sense, single-stranded RNA. The viral genome is $5^{\prime}$ capped, with a poly-A tail and the gene organization is $5^{\prime}$ UTR-1a/lab-S-3a-3b-E-M$5 \mathrm{a}-5 \mathrm{~b}-\mathrm{N}-3^{\prime}$ UTR. The $5^{\prime}$ two-thirds of the IBV genome encodes two polyproteins la and lab that contain nonstructural proteins which are associated with viral RNA replication and transcription, whereas the $3^{\prime}$ one-third encodes four structural proteins: the surface spike glycoprotein $(\mathrm{S})$, and small envelope (E), membrane $(\mathrm{M})$, and nucleocapsid $(\mathrm{N})$ proteins [5].

Virus isolation is the "gold standard" for the diagnosis of IBV infection. Since there is lack of cell lines to support the growth of IBV, 9- to 11-day-old embryo inoculation via the allantoic route is commonly used for virus isolation. The characteristic embryo changes, such as dwarfing, stunting, or curling of embryos, can be observed between 2 and 7 days after the inoculation. This type of diagnosis assay has been used for many years. However, for most of the field samples, several blind passages (more than three times) were needed before typical characteristic embryo changes can be observed, and interpretation of the results was subjective. In addition, this method is time consuming (2-7 days for each passage are needed before embryo lesions can be observed) and expensive (requires a large amount of embryos) [4, 6, 7].

In order to obtain rapid and accurate diagnostic results, more sensitive molecular methods for the detection of IBV have been developed, including reverse-transcriptase polymerase chain reaction (RT-PCR), and real-time RT-PCR [8]. Primer pairs targeting to the $3^{\prime}$ untranslated region (UTR), $\mathrm{N}$ gene, and the SI and S2 parts of the $S$ gene of IBV genome have been reported to detect as many as possible, although not all, isolates of IBV [8-12]. Furthermore, the DNA fragment produced from the RT-PCRbased method can be further sequenced for phylogenetic analysis.

The $\mathrm{N}$ gene and $3^{\prime}$ UTR are the most conserved regions in the genome of IBV serotypes [13]. Furthermore, a nested set of IBV subgenomic mRNAs (sgRNAs) is produced via a discontinuous transcription mechanism, and the N gene and $3^{\prime}$ UTR are the most abundant productions during transcription [14, 15]. These characteristics demonstrate that the N gene and $3^{\prime}$ UTR of IBV are the appropriate candidates for molecular diagnosis. In our epidemiology surveillance of IBV in China, we have successfully used a set of primers targeting the $\mathrm{N}$ gene and $3^{\prime}$ UTR to detect IBV in allantoic fluids of embryos inoculated with tissue, oropharyngeal, and cloacal swab samples. In this chapter, we describe the procedures of one-step RT-PCR for the detection of IBV from a range of sample types that were used in our IBV epidemiology surveillance studies. This assay together with virus isolation is designed specifically for the rapid detection of serotypes of IBV from clinical samples. 


\section{Materials}

2.1 Sample Handing

2.2 RNA Extraction

\subsection{IBV One-Step RT-PCR}

1. 9- to 11-day-old embryonated SPF chicken eggs ( see Note 1).

2. Sterile phosphate-buffered solution (PBS). Store at room temperature.

3. Viral transport medium for swabs $(500 \mathrm{ml}$ PBS containing $0.1 \mathrm{~g}$ gentamicin, $0.25 \mathrm{~g}$ kanamycin, $1.25 \mathrm{mg}$ amphotericin $\mathrm{B}$, and $5 \mathrm{ml}$ equine serum). Store at $-20{ }^{\circ} \mathrm{C}$.

4. Oropharyngeal and cloacal swabs and tissue samples from the kidney, proventriculus, trachea, and caecal tonsil from commercial flocks of cockerels, broilers, pullets, layers, and breeders suspected of IBV infection (see Notes 2 and 3). Store at $-70{ }^{\circ} \mathrm{C}$.

5. TissueLyser II (Qiagen, Germany).

1. TRIzol reagents (Invitrogen, Grand Island, New York, USA). Store at $4{ }^{\circ} \mathrm{C}$.

2. RNase-free Water (TaKaRa, Dalian, China). Store at room temperature.

3. Chloroform. Store at room temperature.

4. Isopropyl alcohol. Store at room temperature.

5. $75 \%$ Ethanol (in RNase-free water). Store at $-20^{\circ} \mathrm{C}$.

1. The primers are prepared in a stock solution of $100 \mu \mathrm{M}$ with RNase-free water. A working solution of $10 \mu \mathrm{M}$ is made for use in the RT-PCR. Store at $-20^{\circ} \mathrm{C}$ until use.

Forward primer: $\mathrm{N}(+) 5^{\prime}$-GACGCCCCAGCGCCAGTCATTA AA- $3^{\prime}$.

Reverse primer: N (-) 5'-ACGCGGAGTACGATCGAGGG TACA-3' (TaKaRa, Dalian, China) (see Note 4).

2. TaKaRa PrimeScript One Step RT-PCR Kit Ver.2 containing PrimeScript 1 Step Enzyme Mix, $2 \times 1$ Step Buffer, and RNase Free $\mathrm{dH}_{2} \mathrm{O}$ (TaKaRa, Dalian, China). Store all reagents at $-20{ }^{\circ} \mathrm{C}$.

3. TaKaRa PCR Thermal Cycler Dice ${ }^{\mathrm{TM}}$ Gradient TP600 (TaKaRa, Dalian, China).

1. $1 \times$ Tris-acetate-EDTA (TAE) buffer. Store at room temperature.

2. Agarose gels ( $1 \%$ agarose in $1 \times$ TAE buffer containing $0.5 \mu \mathrm{g} /$ $\mathrm{ml}$ ethidium bromide).

3. 250 bp DNA Ladder (Dye Plus) (TaKaRa, Dalian, China). Store at $4{ }^{\circ} \mathrm{C}$.

4. ChemiDocMP Imaging System (Bio-Rad, Hercules, CA, USA).

5. E.Z.N.A. Gel Extraction Kit (Omega Bio-Tek, USA). Store at room temperature. 


\subsection{PCR Product Cloning}

\subsection{Sequencing and Sequence Analysis}

1. pMD 18-T Vector Cloning Kit (TaKaRa, Dalian, China). Store at $-20{ }^{\circ} \mathrm{C}$.

2. DH5 $\alpha$ competent cells kit (TaKaRa, Dalian, China). Store at $-70{ }^{\circ} \mathrm{C}$.

3. LB plate containing $100 \mu \mathrm{g} / \mathrm{ml}$ ampicillin, $24 \mu \mathrm{g} / \mathrm{ml} \mathrm{X}-\mathrm{Gal}$, and $40 \mu \mathrm{g} / \mathrm{ml} \mathrm{IPTG}$. Store at $4{ }^{\circ} \mathrm{C}$.

4. LB liquid culture medium containing $100 \mu \mathrm{g} / \mathrm{ml}$ ampicillin. Store at $4{ }^{\circ} \mathrm{C}$.

5. Premix Taq (Ex TaqVersion 2.0) (TaKaRa, Dalian, China). Store at $-20{ }^{\circ} \mathrm{C}$.

1. Sequencing: At least three clones were sequenced each time.

2. DNASTAR's Lasergene Sequence Analysis Software.

3. Molecular Evolutionary Genetics Analysis (MEGA) Software.

\section{Methods}

\subsection{Sample Handling}

\subsection{RNA Extraction}

1. Tissue samples: Homogenize the tissue samples as $10 \%$ weight/volume tissue suspensions in PBS by using TissueLyser II (Qiagen, Germany), freeze-thaw three times at $-20{ }^{\circ} \mathrm{C}$ and room temperature, and then clarify by centrifugation at $1500 \times g$ at $4{ }^{\circ} \mathrm{C}$ for $10 \mathrm{~min}$; use $200 \mu \mathrm{l}$ of the supernatant to inoculate into the allantoic cavity of 9-day-old to 11 -day-old SPF embryos. At 3 days after inoculation, take $200 \mu$ l allantoic fluid for viral RNA extraction. Store the rest of the sample at $-80{ }^{\circ} \mathrm{C}$ ( see Notes 1, 5-6).

2. Swab samples: Place the tip of the swab in a $1.5 \mathrm{ml}$ EP tube containing $1 \mathrm{ml}$ viral transport medium. After squeezing the tip of the swap and vortexing, take $200 \mu$ of the solution for embryo inoculation and $200 \mu \mathrm{l}$ allantoic fluid for subsequent viral RNA extraction at 3 days after inoculation. Store the rest of the sample at $-80{ }^{\circ} \mathrm{C}($ see Notes 1,6 , and 7$)$.

Viral RNA was extracted from $200 \mu \mathrm{l}$ of allantoic fluid from embryos that have been inoculated with tissue and oropharyngeal and cloacal swab samples using TRIzol (Invitrogen), which is a reagent that has been used to isolate high quality of total RNA from various types of samples. We followed the manufacturer's instructions with minor changes:

1. Pipette $200 \mu \mathrm{l}$ allantoic fluid into $1.5 \mathrm{ml}$ RNase-free microcentrifuge tube (see Note 8 ).

2. Add $1 \mathrm{ml} \mathrm{TRIzol} \mathrm{reagent} \mathrm{to} \mathrm{each} \mathrm{tube,} \mathrm{and} \mathrm{incubate} \mathrm{for} 5 \mathrm{~min}$ at room temperature after vortexing thoroughly.

3. Add $0.2 \mathrm{ml}$ of chloroform per $1 \mathrm{ml}$ of TRIzol reagent. Shake tube vigorously by hand for $15 \mathrm{~s}$. 
4. Incubate for 2-3 min at room temperature.

5. Centrifuge the tube at $12,000 \times g$ for $15 \mathrm{~min}$ at $4{ }^{\circ} \mathrm{C}$.

6. Transfer the aqueous phase into a new RNase-free tube. Avoid disturbing the interphase or organic layer when removing the aqueous phase.

7. Add $0.5 \mathrm{ml}$ of $100 \%$ isopropanol to the aqueous phase, per $1 \mathrm{ml}$ of TRIzol reagent.

8. Incubate at $-20^{\circ} \mathrm{C}$ for $30 \mathrm{~min}$.

9. Centrifuge the tube at $12,000 \times g$ for $15 \mathrm{~min}$ at $4^{\circ} \mathrm{C}$.

10. Remove the supernatant, leaving the RNA pellet on the bottom of the tube ( see Note 9).

11. Wash the RNA pellet with $1 \mathrm{ml}$ of $75 \%$ ethanol per $1 \mathrm{ml}$ of TRIzol reagent.

12. Vortex the sample briefly, and then centrifuge the tube at $7500 \times g$ for $5 \mathrm{~min}$ at $4^{\circ} \mathrm{C}$. Discard the wash.

13. Air-dry the RNA pellet for 5-10 min ( see Note 10).

14. Resuspend the RNA pellet in RNase-free water.

15. (Optional) Incubate the tube in a water bath at $55-60{ }^{\circ} \mathrm{C}$ for 10-15 min to increase the solubilization rate.

16. The obtained RNA should be stored at $-70{ }^{\circ} \mathrm{C}$ or applied directly for subsequent one-step RT-PCR.

\subsection{IBV One-Step RT-PCR}

1. Detecting a sample for the presence of IBV is performed by amplifying a 1604-bp fragment of the IBV N gene and $3^{\prime}$ UTR using the primer set $\mathrm{N}(+)$ and $\mathrm{N}(-)$ described in Sect. 2.3. We used a one-step RT-PCR kit throughout the procedure (see Note 11). Perform all RT-PCR steps on ice. Prepare the following mix for RT-PCR according to the number of samples to be tested: PrimeScript 1 Step Enzyme Mix $2 \mu$ l, $2 \times 1$ Step Buffer $25 \mu \mathrm{l}$, forward primer $1 \mu \mathrm{l}$, reverse primer $1 \mu \mathrm{l}$, and RNase-free water to $48 \mu \mathrm{l}$ per reaction ( see Note 12).

2. Add $2 \mu \mathrm{l}$ RNA sample to the $0.2 \mathrm{ml} \mathrm{PCR}$ tube containing $48 \mu \mathrm{l}$ of RT-PCR mix, leading to a final reaction volume of $50 \mu \mathrm{l}$. The reaction is carried out with an initial reverse transcription step at $50{ }^{\circ} \mathrm{C}$ for $30 \mathrm{~min}$, followed by PCR activation at $94{ }^{\circ} \mathrm{C}$ for $2 \mathrm{~min}, 30$ cycles of amplification $\left(30 \mathrm{~s}\right.$ at $94{ }^{\circ} \mathrm{C} ; 30 \mathrm{~s}$ at $60{ }^{\circ} \mathrm{C} ; 2$ min at $72{ }^{\circ} \mathrm{C}$ ), and a final extension step at $72{ }^{\circ} \mathrm{C}$ for $10 \mathrm{~min}$ in PCR Thermal Cycler Dice ${ }^{\mathrm{TM}}$ Gradient TP600 (see Notes 13 and 14).

1. Load $4 \mu \mathrm{l}$ of PCR product mixed with $1 \mu$ l loading buffer on a $1 \%$ agarose gel. Load $5 \mu \mathrm{l} 250$ bp DNA Ladder on the left side of the gel. Run the gel at $180 \mathrm{~V}$ for $20 \mathrm{~min}$. Visualize the bands by illuminating the gel with UV light on the Bio-Rad ChemiDocMP Imaging System (Bio-Rad, Hercules, CA, USA). 


\subsection{PCR Product Cloning (Optional)}

2. Determination of the products' fragment size is carried out by comparing the length of the bands to 250 bp DNA Ladder. Samples from which a PCR product of approximately $1600 \mathrm{bp}$ is amplified are presumed to be IBV positive.

3. Extraction and purification of PCR product are performed by using E.Z.N.A. Gel Extraction Kit (Omega Bio-Tek, USA) according to the manufacturer's instructions. The purified PCR products are then used as templates for sequencing. Alternatively, these samples could be stored at $-20{ }^{\circ} \mathrm{C}$ until use.

1. Mix $9 \mu \mathrm{l}$ purified PCR products with $10 \mu \mathrm{l}$ solution I and $1 \mu \mathrm{l}$ pMD18-T vector provided by pMD 18-T Vector Cloning Kit (TaKaRa, Dalian, China). Incubate the $20 \mu \mathrm{l}$ mixture at $16{ }^{\circ} \mathrm{C}$ overnight.

2. Thaw a vial of DH5 $\alpha$ competent cells on ice.

3. Add $20 \mu \mathrm{l}$ reaction mixture into the thawed $\mathrm{DH} 5 \alpha$ competent cells; incubate on ice for $30 \mathrm{~min}$ after slightly mixing.

4. Heat shock $90 \mathrm{~s}$ at $42^{\circ} \mathrm{C}$, and then chill on ice for 2-3 min.

5 . Add $1 \mathrm{ml}$ SOC medium provided from the competent cells kit to the transfected cells and incubate at $37^{\circ} \mathrm{C}$ with shaking for $1 \mathrm{~h}$.

6. Centrifuge at $1500 \times g$ for $5 \mathrm{~min}$ and remove $800 \mu \mathrm{l}$ supernatant from the tube.

7. Cells were resuspended in the rest of the medium and then spread onto the LB plate containing $100 \mu \mathrm{g} / \mathrm{ml}$ ampicillin, $24 \mu \mathrm{g} / \mathrm{ml} \mathrm{X}-\mathrm{Gal}$, and $40 \mu \mathrm{g} / \mathrm{ml}$ IPTG. Incubate the plate at $37^{\circ} \mathrm{C}$ overnight in an inverted position.

8. Select and mark white colonies for PCR screening. Use sterile pipette tips to pick the selected colonies and then transfer the tips into tubes with $5 \mathrm{ml} \mathrm{LB}$ containing $100 \mu \mathrm{g} / \mathrm{ml}$ ampicillin; incubate these tubes at $37^{\circ} \mathrm{C}$ overnight with shaking.

9. Identify the bacteria culture through PCR using forward primer: $\mathrm{N}(+)$ and reverse primer: $\mathrm{N}(-)$.

Prepare the following reaction mix for PCR: Premix Taq $12.5 \mu \mathrm{l}$, forward primer: $\mathrm{N}(+) 1 \mu \mathrm{l}$, reverse primer: $\mathrm{N}(-) 1 \mu \mathrm{l}$, bacteria culture $1 \mu \mathrm{l}$, and sterilized water up to $25 \mu \mathrm{l}$. PCR thermocycler is set at the following conditions: 10 -min incubation at $94^{\circ} \mathrm{C}, 30$ cycles of $94^{\circ} \mathrm{C}$ for $30 \mathrm{~s}$, annealing at $60{ }^{\circ} \mathrm{C}$ for $30 \mathrm{~s}$, and $72{ }^{\circ} \mathrm{C}$ for $2 \mathrm{~min}$, and a final extension step at $72{ }^{\circ} \mathrm{C}$ for $10 \mathrm{~min}$.

10. Agarose gel electrophoresis is used to determine the size of the inserts of these clones according to the procedures described in Sect. 3.4. Clones with the expected product sizes will be selected for sequencing. 


\subsection{Sequence Analysis}

The nucleotide sequences of the IBV serotypes are assembled, aligned, and compared with those of other reference IBV serotypes using DNASTAR's Lasergene Sequence Analysis Software. A Maximum Likelihood tree based on the JTT matrix-based model and 100 bootstrap replicates was built using the MEGA 4.

\section{Notes}

1. In order to determine the sensitivity of the diagnostic IBV RT-PCR assay, we compared this assay with the current standard test, virus isolation in SPF embryos. A tenfold dilution series of the IBV H120 strain $\left(10^{7} \mathrm{EID}_{50}\right)$ was prepared; $200 \mu \mathrm{l}$ of each dilution was tested in parallel by both tests. The limit of detection of virus isolation was $0.5 \times 10^{1} \mathrm{EID}_{50}$, while the limit of detection of the RT-PCR was 500 EID $_{50}$. These results showed that this IBV RT-PCR assay is less sensitive than virus isolation for the IBV-infected allantoic fluid. However, we found that after inoculating tissue and oropharyngeal and cloacal swab samples into the allantoic cavities of 9-day-old to 11-day-old SPF embryos, this IBV RT-PCR assay can efficiently detect the IBV in allantoic fluids, and no extra blind passage is needed. In practice, we have successfully used this assay together with virus isolation, to detect most serotypes of IBV from clinical samples during our epidemiology surveillance of IBV in China.

2. Swab sample collection: IBV isolates can infect a large range of epithelial surfaces including respiratory tissues and non-respiratory tissues of chicken. Since the primary target tissue for IBV is the respiratory tract, oropharyngeal swabs is a good choice for detection of IBV especially in the early stages of infection due to that IBV persists in the respiratory tract for a relatively short time after infection. For collecting oropharyngeal swab samples, insert swab into the bird's throat and leave it in place for a few seconds to absorb secretions.

It is considered that replication of IBV in intestinal tract normally does not cause clinical disease, although it does result in faecal excretion of the virus. The excretion of IBV in the faeces may be associated with apparent long-term persistence of IBV in chicken flocks. Therefore, cloacal swab is the material of choice to detect IBV. For collecting cloacal swab samples, insert swab into the bird's cloaca and stir for a few seconds to stick faeces.

3. The selection of tissue material for IBV isolation or detection is critical because IBV can affect many tissues, involving the respiratory, renal, and reproductive systems. In our previous study, we have successfully detected the IBV from kidney, 
proventriculus, trachea, and caecal tonsil from commercial chickens. In practice, trachea tissue can be chosen for IBV detection when chicken showed respiratory symptoms. In addition, kidney and caecal tonsil are candidate materials when investigating kidney infection or declined egg laying performance. If swelling of the proventriculus, the characteristic changes of infected chickens, occurs, proventriculus can be selected as sample for IBV detection.

4. In order to detect as many IBV serotypes as possible, $\mathrm{N}$ protein genes from 228 IBV strains available in GenBank were aligned using the MegAlign application in the Lasergene software package [16]. The forward primer $\mathrm{N}(+)$ targeting a conserved region of IBV $\mathrm{N}$ gene and reverse primer $\mathrm{N}(-)$ targeting the conversed $3^{\prime}$ UTR of the IBV genome were designed. We have successfully detected the Massachusetts, 4/91, LX4, CK/ $\mathrm{CH} / \mathrm{LSC} / 99 \mathrm{I}, \mathrm{CK} / \mathrm{CH} / \mathrm{LDL} / 97 \mathrm{I}$, and Connecticut type of IBV serotypes by using this pair of primers.

The Georgia 98, Arkansas, and Florida (isolated from USA), Australian Group 1, 2, and 3 (identified in Australia), Italy02, and D274 (predominant IBV types identified in Europe, except 793B, Massachusetts, and LX4 types) have not to be tested, due to that these isolates are unavailable in our laboratory. However, the primers $\mathrm{N}(+)$ and $\mathrm{N}(-)$ could also be used to detect these IBV types, because the primers are targeting highly conserved regions among these IBV strains. It should be noted that although the primer targeting regions are conserved, $\mathrm{N}$ gene and $3^{\prime}$-terminal region of $3^{\prime}$ UTR show certain variations among different serotypes. It is likely that primers $\mathrm{N}(+)$ and $\mathrm{N}(-)$ may need slight modification to increase their universality for other IBV serotypes that have not been tested in our study. For example, degeneracy of primers should be considered which has been successfully applied in detection of viruses with genetic diversity.

5. We prepare homogenized tissue suspensions by using the TissueLyser II (Qiagen, Germany) which has been widely applied to sample preparation. The $2 \mathrm{ml}$ microcentrifuge tubes with stainless steel beads for tissue disruption should be sterilized. Precooling the Tissue Lyser Adapter Set in $-80^{\circ} \mathrm{C}$ can reduce the RNA degradation in the process of sample preparation.

6. The repeated freeze-thaw cycles should facilitate viruses releasing from infected tissues. We aliquot the prepared samples (tissue and swab samples) into separate tubes, one tube for virus isolation and subsequent RNA extraction and the others kept at $-80{ }^{\circ} \mathrm{C}$ for long-term storage.

7. Filtration of tissue and swab samples is not recommended because this step will reduce virus titer. 
8. During the RNA extraction process, the most important preventative measure is to avoid RNA degradation caused by RNase contamination. All pipette tips and microcentrifuge tubes should be RNase-free and glove and mask should be worn.

9. The RNA pellet is often invisible and locates at the side and bottom of the tube. Discarding the supernatant should be performed carefully without touching the RNA pellet.

10. Do not allow the RNA to dry completely, which reduces the solubility of the RNA.

11. The one-step RT-PCR kit is employed to reduce the amount of handling required. In our laboratory, we have successfully used it to amplify RT-PCR products of between 1052 and 2849 bp in length from clinical samples.

12. General procedures to prevent PCR cross-contamination should be strictly followed. In order to prevent the detection of false positive, which may occur owing to crosscontamination, preparation of the master mix for RT-PCR should be carried out in an isolated room separate from areas used for sample processing and RNA extraction. If possible, each step of the whole process including sample processing, RT-PCR, and post-PCR analysis should be carried out in separated rooms.

13. To ensure the reliability of results, multiple positive and negative controls should be included in the RT-PCR reactions, especially when unknown clinical samples are tested. The negative control consists of a sample containing only the RT-PCR mix without RNA $(2 \mu$ of water is added instead of RNA). RNA of IBV (e.g., H120) can be used as positive control.

14. When adding the RNA samples to the RT-PCR mix, precaution must be taken to avoid RNA cross-contamination. Avoiding the formation of aerosols by using aerosol-resistant filtered pipette tips can prevent the falsepositive results due to cross-sample contamination caused by aerosol spraying.

\section{Acknowledgments}

This work was supported by grants from the China Agriculture Research System (No. CARS-41-K12) and National "Twelfth Five-Year" Plan for Science \& Technology Support (2015BADl2B03). 


\section{References}

1. Cavanagh D (2007) Coronavirus avian infectious bronchitis virus. Vet Res 38:281-297

2. Han Z, Sun C, Yan B, Zhang X, Wang Y, Li C, Zhang Q, Ma Y, Shao Y, Liu Q (2011) A 15-year analysis of molecular epidemiology of avian infectious bronchitis coronavirus in China. Infect Genet Evol 11:190-200

3. Cavanagh D (2005) Coronaviruses in poultry and other birds. Avian Pathol 34:439-448

4. Cook JKA, Jackwood M, Jones R (2012) The long view: 40 years of infectious bronchitis research. Avian Pathol 41:239-250

5. Jackwood MW, Hall D, Handel A (2012) Molecular evolution and emergence of avian gammacoronaviruses. Infect Genet Evol 12:1305-1311

6. Sun C, Han Z, Ma H, Zhang Q, Yan B, Shao Y, Xu J, Kong X, Liu S (2011) Phylogenetic analysis of infectious bronchitis coronaviruses newly isolated in China, and pathogenicity and evaluation of protection induced by Massachusetts serotype $\mathrm{H} 120$ vaccine against QX-like strains. Avian Pathol 40:43-54

7. Ma H, Shao Y, Sun C, Han Z, Liu X, Guo H, Kong X, Liu S (2012) Genetic diversity of avian infectious bronchitis coronavirus in recent years in China. Avian Dis 56:15-28

8. Cavanagh D (2001) Innovation and discovery: the application of nucleic acid-based technology to avian virus detection and characterization. Avian Pathol 30:581-598

9. Cavanagh D, Mawditt K, Sharma M, Drury SE, Ainsworth HL, Britton P, Gough RE (2001) Detection of a coronavirus from turkey poults in Europe genetically related to infectious bronchitis virus of chickens. Avian Pathol 30:355-368
10. Jones R, Ellis R, Cox W, Errington J, Fuller C, Irvine R, Wakeley P (2011) Development and validation of RT-PCR tests for the detection and Sl genotyping of infectious bronchitis virus and other closely related gammacoronaviruses within clinical samples. Transbound Emerg Dis 58:411-420

11. Meir R, Maharat O, Farnushi Y, Simanov L (2010) Development of a real-time $\operatorname{TaqMan}(\mathrm{R})$ RT-PCR assay for the detection of infectious bronchitis virus in chickens, and comparison of RT-PCR and virus isolation. J Virol Methods 163:190-194

12. Callison SA, Hilt DA, Boynton TO, Sample BF, Robison R, Swayne DE, Jackwood MW (2006) Development and evaluation of a realtime Taqman RT-PCR assay for the detection of infectious bronchitis virus from infected chickens. J Virol Methods 138:60-65

13. Williams AK, Wang L, Sneed LW, Collisson EW (1992) Comparative analyses of the nucleocapsid genes of several strains of infectious bronchitis virus and other coronaviruses. Virus Res 25:213-222

14. Zhao X, Shaw K, Cavanagh D (1993) Presence of subgenomic mRNAs in virions of coronavirus IBV. Virology 196:172-178

15. Enjuanes L, Almazán F, Sola I, Zuiga S (2006) Biochemical aspects of coronavirus replication and virus-host interaction. Annu Rev Microbiol $60: 211-230$

16. Han Z, Zhao F, Shao Y, Liu X, Kong X, Song Y, Liu S (2013) Fine level epitope mapping and conservation analysis of two novel linear B-cell epitopes of the avian infectious bronchitis coronavirus nucleocapsid protein. Virus Res 171:54-64 